Uşak Üniversitesi Sosyal Bilimler Dergisi

$2015,8 / 4$

\title{
Akademisyenlerin Adalet ve Etik Algılarının Örgütsel Adanmışlıklarına Etkisi
}

\author{
Muhittin Fatih DEMİRHAN ${ }^{*}$ \\ Adil KARAMAN**
}

\section{Öz}

Nedensel tarama modeli kullanılarak yapılan bu araştırmanın amacı, Uşak Üniversitesi bünyesinde çalışan akademisyenlerin adalet ve etik algılarının örgütsel bazda adanmışlıklarını etkileme düzeyini belirlemeye yöneliktir. Araştırmanın evrenini 2012-2013 yılı güz yarıyılında Uşak Üniversitesinde çalışan 365 akademik personel oluşturmaktadır. Araştırmanın örneklemi ise evren içinden basit tesadüfi örnekleme yöntemi ile seçilen 181 katılımcıdan oluşmaktadır. Araştırmanın verileri, akademisyenlerin adalet algılarını, etik algılarını ve adanmışlık düzeylerini belirleyebilmek amacıyla 3 farklı ölçme aracı kullanılmak suretiyle toplanmıştır. Toplanan veriler betimsel istatistikler, faktör analizi ve regresyon analizine tabi tutulmuştur. Elde edilen bulgular, adalet algısı kavramı içerisinde yer alan boyutlardan dağıtım adaletinin ve etik algısının akademik personelin adanmışlık düzeyini istatistiksel olarak anlamlı bir biçimde etkilediği yönündedir.

Anahtar Kelimeler: Örgütsel Adanmışlık, Örgütsel Etik, Örgütsel Adalet.

\section{Academics' Perceptions of Organizational Justice and Ethical Impact of Dedication}

\begin{abstract}
The aim of this study, designed in casual survey model, is to determine the effects of perceived Organizational justice and ethics on Organizational commitment levels of academicians working in Uşak University. Research universe includes 365 academicians working in Uşak University at 2012-2013 academic year. Sample of the study is 181 participants, selected by simple random sampling method from the universe. Data of the Research was gathered by using 3 different scales
\end{abstract}

* Öğr. Gör., Uşak Üniversitesi, Sivaslı MYO, Pazarlama ve Dış Tic. Bölümü

** Yrd. Doç. Dr., Uşak Üniversitesi, İ̈BF, İşletme Bölümü 
intended to measuring perceived organizational justice, ethics and Organizational commitment levels of academicians. Data was subjected to descriptive statistics, factor analysis and regression analysis. According to the findings, distribution justice subfactor of Organizational justice perception and ethics perception affects Organizational commitment level significantly.

Keywords: Organizational Commitment, Organizational Ethics, Organizational Justice.

\section{Giriş}

Adalet ve etik kavramları güvenin temelini oluşturan, çalışanların kurumlara olan inançlarını kuvvetlendiren davranışsal ve psikolojik birer olgudurlar. Güveni etkileyen birçok faktör vardır. Bu faktörlerden en önemlileri örgüt içindeki adalet anlayışı ve etik anlayışıdır. Örgüt içindeki adalet anlayışı ve etik anlayışının birleşiminin literatürde "örgütsel güven" olarak adlandırıldığı görülmektedir.

Üniversiteler, daha çağdaş ve bilgi düzeyi yüksek bir toplum oluşturma amacı güden örgütlerdir. Üniversiteler bireylerin akademik açıdan kendilerini daha ileri düzeylere taşıyabilecekleri en ideal yapılardır. Üniversitelerin dış çevreleri ile (ekonomik, sosyal ve kültürel çevre) düzenli ilişkide olmaları çağdaş bir anlayışı da ortaya çıkarmaktadır. Ancak, iç çevresi (çalışanlar, paydaşlar) ile düzenli ve olumlu ilişkiler kuramayan örgütlerin diş çevresi ile iyi ilişkiler içerisinde olması beklenemez. Üniversitelerin iç çevresini oluşturan en önemli unsur ise akademik personeldir.

Bu çalışmada, akademik personelin adalet algısının ve etik algısının örgütsel adanmışlıklarına etkisi incelenecektir.

\section{Problem Durumu ve Araștırmanın Önemi}

Örgütlerde personelin amaçlarıyla, örgütün amaçlarının örtüşmesi örgütsel başarının sağlanmasında büyük önem arz etmektedir. Örgüt personelinin örgütsel adanmışlıkları arttıkça örgüt amaçlarını benimseme düzeyleri de artmaktadır. Dolayısıyla, personelin fedakârlık yapma duyguları artmakta, örgütle özdeşleşmektedir. Sonuç olarak personel örgüt üyeliğini gönüllü olarak sürdürmektedir. Örgütsel adanmışlığın sağlanmasındaki en büyük etmenin, personelin örgüte güven duyması olduğu düşünülmektedir. Örgüte duyulan güven, örgütsel adalet ve örgütsel etik kavramlarını da içine alan, çalışanların örgütlere olan inançlarını kuvvetlendiren davranışsal ve psikolojik bir olgudur. 
Bu çalışmada araştırılan akademik personelin örgütsel adalet ve örgütsel etik algıları literatürde kısıtlı olarak ele alınmıştır. Çalışmamızda öncelikle örgütsel adalet ve örgütsel etik kavramları incelenerek bu kavramların akademik personelin örgütsel adanmışlığına etkileri ele alınacaktır.

\section{Araştırmanın Amacı ve Alt Problemler}

$\mathrm{Bu}$ araştırmanın amacı akademik personelin örgütsel adalet algılarının, örgütsel etik algılarının örgütsel adanmışlık düzeyleri üzerindeki etkisini belirlemektir. Bu amaç doğrultusunda aşağıdaki araştırma sorularına cevap aranmıştır;

- Akademik personelin örgütsel adalet algı ortalamaları, etik alg1Sı ortalamaları ve örgütsel adanmışlık ortalamaları betimsel olarak ne düzeydedir?

- Akademik personelin örgütsel adanmışlık düzeyleri; cinsiyet, yaş, medeni durum, akademik unvan, kurumda çalışma süresi, idari görev alıp almama ve idari görev yapma süresi gibi demografik özelliklerine göre farklılaşmakta mıdır?

- Akademik personelin örgütsel adalet algıları, etik algıları ve demografik özellikleri, örgütsel adanmışlık düzeylerini ne derecede etkilemektedir?

Aşağıda yer alan başlıklarda örgütsel adalet, örgütsel etik ve örgütsel adanmışlık kavramlarına yer verilecektir.

\section{Örgütsel adalet kavramı}

Adalet kavramı, haklılık ve doğruluğun ifadesi olarak kullanılmakta ve kavramın kökünü oluşturan "adl" sözcügü İngilizcedeki "justice"in karşılığını oluşturmaktadır. Justice sözcüğünün kökünü oluşturan "just" ise bir sistemin veya düzenin iyi işlemesi için gerekenin yapılması olarak nitelendirilmektedir (Kaya, 2008: 232).

Günlük dilimizde "adalet" kavramı; bir davranışın veya hareketin, adalete uygunluğunu, doğruluğunu ve bireylerin dürüstlüğünü ifade etmek için kullanılır. Örgütsel ortamlarda, "örgütsel adalet" kavramı ise; örgütlerle ilgili olarak yöneticilerin adaletli ya da adil olma durumunu tanımlamak için kullanılmaktadır (Pillai vd., 1999:900, Colquitt vd., 2001: 425).

Türk Dil Kurumu'na göre adalet "yasalarla sahip olunan hakların herkes tarafından kullanılmasının sağlanması, hak ve hukuka uygunluk" olarak tanımlanmıştır (http://tdkterim.gov.tr). 
Literatürde adalet ile ilgili olarak yapılmış tanımlara baktığımızda, adaleti en genel anlamıla hakların, düşüncelerin ve özgürlüklerin güvence altına alınması, hakların adil olarak belirlenmesi ve eşit olarak dağıtılması ve haklıyla haksızın birbirinden ayrılması ve yasalara uygunluk olarak tanımlayabiliriz.

Çalışmamızda ele aldığımız örgütsel adalet kavramı ile ilgili çalışmaların temelini, Stouffer'ın "Göreli Yoksunluk", Homans'ın "Dağıtım Adaleti" ve Adams'ın "Eşitlik Teorisi" oluşturmaktadır. Adams'ın 1965 yılında geliştirdiği eşitlik teorisinde, bireylerin işyerindeki başarıları ve bundan tatmin olma derecesinin çalıştığı ortamla ilgili olarak algıladığ eşitlik veya eşitsizlikle yakından alakalı olduğu belirtilmektedir. Bireylerin, çalıştığı işletmeyle, yaptığı işle ve yöneticileriyle ilgili oluşturduğu bir takım tutumlar bireyin çalışma ortamına ilişkin adalet algılamasını ortaya çıkarmaktadır (Cihangiroğlu, 2010).

Örgütsel adalet; çalışanların görev dağılımı, mesaiye uyma, yetki verilmesi, ücret düzeyi, ödül dağıtımı gibi değişkenlere yönelik, yönetsel kararları değerlendirme sürecidir. Bu açıdan değerlendirildiğinde örgütsel adaletin, örgüt yönetiminin karar ve uygulamalarının çalışanlar tarafından nasıl algılandığı ile ilgili bir kavram olduğu ifade edilebilir (İnce ve Gül, 2005: 76).

Yapılan bu tanımlar çerçevesinde örgütsel adalet; yöneticilerin örgüt ve çalışanlarla ilgili karar ve uygulamalarının, çalışanlar tarafından olumlu şekilde algılanması olarak tanımlanabilir. Başka bir ifadeyle örgütsel adalet; örgüt içerisinde ücretlerin, ödüllerin, cezaların ve terfilerin nasıl yapılacağı, bu tür kararların nasıl alındığı ya da alınan bu kararların çalışanlara nasıl söylendiğinin, çalışanlarca, algılanma biçimi olarak tanımlanabilir.

Çalışanlarda ortaya çıkan bu algılar bu alanda daha önce yapılmış bazı çalışmalarda dağıtım ve işlem adaleti olarak ifade edilen iki farklı adalet algısının sonucu olarak görülürken, bazı çalışmalarda ise bu ayrım etkileşim adaletinin eklenmesiyle üç başlık altında ele alınmıştır. Bunlar, Adams'in eşitlik teorisi ve Leventhal'in adalet yargı modelinin oluşturduğu dağıtım adaleti, kontrol modeli, değer açıklayıcı model, grup değeri modeli ve prosedür tercih modelinin oluşturduğu prosedürel adalet ve doğru sözlülük, saygı, sorularda yerindelik ve açıklama niteliklerinden oluşan etkileşim adaletidir.

\section{Etik Alg1sı Kavramı}

Etik sözcüğü Yunanca "karakter" anlamina gelen "ethos" sözcügünden türemiştir (Şimşek, Akgemci ve Çelik, 2008: 475). Bir felsefe dalı olan etik hakkında Sokrates, Plato ve Aristo gibi filozofların çeşitli görüşleri vardır. Etik kavramının literatürümüze yerleşmesi 1980'li yılların 
sonlarına uzanır. Türkçede etik sözcüğü ahlak sözcügüule eş anlamlı kullanilır.

Etiği en genel anlamıla bireyin yapmış olduğu her davranışın hesabını vicdanlarda verme sorumluluğu olarak tanımlayabiliriz. Hesabı vicdanlarda verme sorumluluğuyla anlatılmak istenen, yapılan davranışların neye dayanılarak, hangi nedenlerle yapıldığının kabul edilebilir gerekçelerle açıklanabilmesidir.

Etik hayatın her alanına etki eden bir kavramdır. Bir takım amaçlarını gerçekleştirmek için kurulmuş örgütlerin de etik konusunun üzerinde önemle durmaları gerekmektedir. Örgütlerin, amaçlarına ulaşabilmek, çağa ayak uydurabilmek, rekabetçi dünyada devamlılıklarını sağlayabilmek için en önemli kaynaklarından biri olan insan unsurunu etkili kullanmaları gerekmektedir. Aynı zamanda, örgütlerin toplumsal anlamda da sorumlulukları vardır. İşte hem çalışanlarını etkili kullanmak hem de toplumsal sorumluluklarını yerine getirmek için etik ilkelerini benimsemiş olmaları gerekmektedir. Etik hem bireysel hem de toplumsal anlamda istenilen ve olması gereken yaşam şartlarının belirlenmesidir.

Etik kavramı, kültür, norm, değerler ve ahlak öğelerinden oluşmaktadır. Literatürde pek çok şekilde karşımıza çıkan kültür kavramı insanların ortaya koyduğu davranışlarının belirleyicisi olarak ifade edilebilir (Özkalp, 2001: 93-94). Uyulması gereken ve toplumsal ilişkileri düzenleyen kurallar bütünü olarak ifade edebileceğimiz norm kavramı, etik kavramının diğer bir unsurunu oluşturmaktadır. Etik kavramının bir diğer unsuru olan ahlak kavramı ise belli sınırlar içerisinde, başkalarını gözeterek yapılan davranışlar olarak özetlenebilir. Bir şeyin önemini belirleyen soyut ölçü olan değerler kavramı ise etik kavramının son unsurudur.

Etik kavramın boyutları ise bireysel boyut, örgütsel boyut ve toplumsal boyuttur.

\section{Örgütsel Etik}

Örgütsel etik, “örgütlerde karar alma sürecinde değerlerin yansıtılma kapasitesi olarak tanımlanabilir. Etik, aynı zamanda çeşitli grupları etkileyen bu değer ve kararların nasıl tanımlanacağını ve yöneticilerin işletme yönetiminde bu zorunlulukları nasıl uygulayacağını gösteren bir kavramdır" (Özkalp ve Kırel, 2004: 232).

\section{Örgütlerde Etik İlkelerin Bileşenleri}

Etik kavramı genel ve örgütsel anlamda tüm toplumu kavradığ 1 için diğer toplumsal kavramlarla da dolaylı veya dolaysız yönlerden ilişki 
içerisindedir. Bu kavramların bir kısmı bileşen, bir kısmı da bağlayıcı unsur olma özelliği arz eder.

Etik ilkelerin bileşenleri olarak tanımlayabileceğimiz liderlik, motivasyon, örgüt iklimi, örgüt kültürü, kişisel farklılık ve yetenekler ile norm ve standartlar birer tamamlayıcı bileşen olarak örgütsel etiğin oluşmasına katkı sağlar.

Örgütlerdeki etik standartlar, açıklık, adalet, eşitlik, dürüstlük ve doğruluk, hak ve özgürlükler, hukukun üstünlüğü, sayg1 ve hoşgörü, sorumluluk ve tarafsızlık olarak sıralanabilir. Ayrıca, örgütlerde sıkça görülen etik dışı davranışlar ise ayrımcllık, görev ve yetkinin kötüye kullanımı, kayırma, kötü alışkanlıklar, mobbing, rüşvet ve yolsuzluk olarak karşımıza çıkmaktadır.

\section{Örgütsel Adanmışlık}

Türkiye'de yapılan çalışmalarda örgütsel bağlılığın başlıca iki anlamından söz edildiği görülmektedir. Buna göre Tuncer (1995) ve Varoğlu (1993) bu kavramı, örgütsel bağlılık; Balcı (2000) ve Celep (2000) ise örgütsel adanmışlık şeklinde adlandırmışlardır (Balay, 2000). Bu çalışmada, bu kavramın karşılığı olarak "örgütsel adanmışlık" kullanılmıştır. Bağlılık ve adanmışlık kavramları birbirini tamamlayan kavramlar olarak kabul edilmiştir.

Adanmışlık: Birisinin eylemleri ile sınırlı olan veya formal, normatif beklentileri aşan davranışlar olarak ifade edilmektedir. Balay (2000) ise aşağıdaki tanımları aktarmaktadır:

- İş görenin örgütte kalma ve onun için çaba gösterme arzusu ile örgütün amaç ve değerlerini benimsemesi (Morrow, 1983: 491; Randalı ve Cote, 1991);

- Kişinin kimliğini örgüte bağlayan tutum ve eğilimler (Sheldon, 1971);

- İş görenin iş yerine psikolojik olarak bağlanması (Beekervd, 1996);

- Kişinin belli bir hareket tarzına bağlılı̆̆1; açık bir ödül veya ceza olmasa bile yapılanı sevme ve ona devam etme isteği (Schwenk, 1986);

Örgütsel adanmışlık üç düzeyde incelenmiştir. Bunlar, düşük adanmışlık düzeyi, ılımlı adanmışlık düzeyi ve yüksek adanmışlık düzeyidir.

Allen ve Meyer'in (1990) geliştirdiği modelde örgütsel adanmışlık ise üç ayrı yaklaşımla ele alınmaktadır. Bunlara örgütsel adanmışlık boyutları da denilmektedir. Bunlar, duygusal adanmışlık, devam adanmışlığı ve normatif adanmışlıktır. Duygusal adanmışlıkta (affective commitment) bireyler, istedikleri için; devam adanmışlı̆̆ında (continuance commitment) gereksim duydukları için; normatif adanmışlıkta (normative 
commitment) ise yükümlülük hissettikleri için örgütte kalırlar. Buna göre işgören, bu psikolojik durumların her birini farklı derecelerde yaşayabilir.

\section{Örgütsel Adanmışlığı Etkileyen Faktörler}

Örgütsel adanmışlığı etkileyen ve belirleyen çeşitli faktörlerden söz edilebilir. Schwenk (1986) bu faktörleri, geçmişteki iş yaşantıları, kişiseldemografik, örgütsel-görevsel ve durumsal nitelikte olanlar şeklinde ayırmıştır (Balay, 2000: 51).

\section{Örgütsel Adanmışlık Odakları}

İşgörenlerin örgütsel adanmışlığı çok boyutlu olup, adanma odakları ve dayanakları işgören eğilim ve davranışlarının kestiriminde önemli bir role sahiptir. Bunlar, örgüte adanmışlık (çalışmamızda okula adanmışlık olarak ele alınmaktadır), mesleğe adanmışlık, çalışma grubuna adanmışlık, işe adanma (çalışmamızda öğretim işlerine adanmışlık olarak ele alınmaktadır), yönetime adanmışlık ve kariyere adanmışlıktır.

\section{Yöntem}

\section{Araştırma Deseni}

Bu çalışmada akademisyenlerin örgütsel adalet ve etik algılarının ve bazı demografik değişkenlerin, örgütsel adanmışlık düzeylerini ne düzeyde açıkladığının belirlenmesi amaçlanmıştır. Bu nedenle çalışma betimsel nitelikte bir çalışma olup, tarama modelinde desenlenmiştir. Tarama modelleri geçmişte ya da hala var olan bir durumu var olduğu şekilde betimlemeyi amaçlayan yaklaşımdır. Araştırmaya konu olan olay, birey ya da nesne, kendi koşulları içinde ve olduğu gibi tanımlanmaya çalışılır. Onları herhangi bir şekilde değiştirme, etkileme çabası gösterilmez. Bilinmek istenen şey vardır ve oradadır. Önemli olan onu uygun biçimde gözleyip belirleyebilmektir (Karasar, 2009: 77).

\section{Evren ve Örneklem}

Evren

$\mathrm{Bu}$ araştırmanın evreni 2012-2013 eğitim öğretim yılı güz yarıyılında, Uşak Üniversitesi bünyesinde bulunan 5 fakülte, 1 sağlık yüksekokulu, 6 meslek yüksekokulunda görev yapmakta olan araştırma görevlisi, okutman, uzman, öğretim görevlisi ve öğretim üyeleri olmak üzere toplam 365 akademik personel ile sinırlıdır.

Örneklem

Araştırmanın örneklemi evren içinden basit tesadüfî örnekleme yöntemi ile seçilmiştir. Anket formları evren büyüklüğü kadar çoğaltılmış, 
bütün akademik personelin mesai saatlerinde ders dışı zamanlarını geçirdikleri ve sıkça bulundukları odalarına en az 3'er defa gidilmek sureti ile elden dağıtılmıştır. Anketlerin doldurulması için yeteri kadar beklendikten sonra (anket formunu doldurmayı kabul eden her akademisyen için 1 hafta) anketler yine odalar tek tek ziyaret edilerek elden toplanmıştır. Anketleri dağıtma ve toplama için geçen süre yaklaşık 3 haftadır. Geri dönen anket sayısı 203'tür. Dönen anket formları tek tek incelenmiş, özensiz ve rastgele dolduruldukları için 22 anket formu değerlendirilme dışı bırakılmıştır.

Araştırmanın örneklemini elde bulunan 181 anket formunu dolduran akademik personel oluşturmaktadır. Örneklemin evreni temsil noktasında sayıca yeterliliğinin sınanması için yapılan hesaplamada 365 kişilik bir evren içinden 181 kişilik bir örneklem grubu için \%95 güven aralığında hata payı \%5,17 olarak hesaplanmıştır ve bu hata payı kabul edilebilir bir aralıktadır. Örnekleme dair detaylı demografik bilgiler Tablo 1 'de görülmektedir.

Tablo 1. Örneklemin Demografik Değişkenlere Göre Dağılımı

\begin{tabular}{|c|c|c|c|c|c|c|c|}
\hline \multirow{4}{*}{ Cinsiyet } & & $\mathrm{f}$ & $\%$ & \multirow{6}{*}{$\begin{array}{l}\text { Kurumda } \\
\text { Çalışma } \\
\text { Süresi }\end{array}$} & & $\mathrm{f}$ & $\%$ \\
\hline & Kadın & 80 & 44 & & $0-3$ & 63 & 35 \\
\hline & Erkek & 101 & 56 & & $4-6$ & 44 & 24 \\
\hline & $0-29$ & 51 & 28 & & $7-9$ & 22 & 12 \\
\hline \multirow{5}{*}{ Yaş } & $30-34$ & 55 & 31 & & $10-12$ & 17 & 10 \\
\hline & $35-39$ & 28 & 15 & & $13-15$ & 4 & 2 \\
\hline & $40-44$ & 30 & 16 & \multirow{6}{*}{ Birim } & 16 ve üzeri & 31 & 17 \\
\hline & $45-50$ & 13 & 8 & & Fakülte & 94 & 53 \\
\hline & 50-üzeri & 4 & 2 & & Enstitü & 8 & 4 \\
\hline \multirow{2}{*}{$\begin{array}{l}\text { Medeni } \\
\text { Durum }\end{array}$} & Evli & 110 & 61 & & Yüksekokul & 13 & 7 \\
\hline & Bekâr & 71 & 39 & & M.Y.O. & 58 & 32 \\
\hline \multirow{6}{*}{$\begin{array}{l}\text { Akademik } \\
\text { Unvan }\end{array}$} & $\begin{array}{l}\text { Öğretim } \\
\text { Görevlisi }\end{array}$ & 69 & 38 & & Rektörlük & 8 & 4 \\
\hline & $\begin{array}{l}\text { Okutman- } \\
\text { Uzman }\end{array}$ & 6 & 3 & \multirow{2}{*}{$\begin{array}{l}\text { İdari } \\
\text { Görev }\end{array}$} & Hayır & 102 & 57 \\
\hline & $\begin{array}{l}\text { Araştırma } \\
\text { Görevlisi }\end{array}$ & 41 & 23 & & Evet & 79 & 43 \\
\hline & Yrd.Doç.Dr. & 57 & 31 & \multirow{2}{*}{$\begin{array}{l}\text { İdari } \\
\text { Görev }\end{array}$} & $0-1$ & 26 & 33 \\
\hline & Doç.Dr. & 7 & 4 & & $2-4$ & 40 & 51 \\
\hline & Prof.Dr. & 1 & 1 & Süresi & $\begin{array}{l}5-7 \\
8 \text { ve üzeri }\end{array}$ & $\begin{array}{l}4 \\
9\end{array}$ & $\begin{array}{c}5 \\
11\end{array}$ \\
\hline
\end{tabular}




\section{Veri toplama araçları}

Araştırma kapsamında veri toplama aracı olarak cinsiyet, yaş, medeni durum, akademik unvan, kurumda çalışma süresi, görev yapılan birim, idari görev alıp almaması ve aldıysa idari görev süresi gibi değişkenleri kapsayan demografik özellikler bölümü ile birlikte Örgütsel Adalet, Etik ve Örgütsel Adanmışlık ölçekleri olmak üzere toplam dört bölümden oluşan bir anket formu kullanılmıştır (Bkz Ek 1). Anket formunda yer alan her üç ölçeğinde literatürde sıkça karşılaşılan ve sıkça kullanılıp geçerlilik güvenilirlik çalışmaları yapılmış ölçekler olması sebebiyle pilot uygulamalarının yapılmasına gerek duyulmamıştır.

Örgütsel Adalet Ölçeği

Araştırmada veri toplama aracı olarak kullanılan Topaloğlu (2010) tarafından geliştirilen ve kullanımı için gerekli izinler alınan Örgütsel Adalet ölçeğinin yapı geçerliliğinin sınanması amacıyla temel bileşenler analizi yapılmıştır. Analiz sonuçlarına göre KMO örneklem yeterliliği değeri $(0,917)$ ve Bartlett küresellik testi anlamlılık düzeyi $(0,000)$ olarak hesaplanmıştır. Örneklemin uygunluğu ile ilgili bu değerler ölçeğin kullanıma uygun olduğu sonucunu göstermektedir.

Yapılan faktör analizi sonucunda iki madde (ölçekte yer alan 5. ve 6 . Maddeler) faktör yüklerinin düşük olması sebebiyle analiz dışı bırakılmıştır. Geri kalan 18 madde ise 3 boyutta toplanmaktadır. Ölçeğin 3 boyutta açıkladığı toplam varyans \%75,30'tür. Ölçeğin tamamına ait cronbach $\alpha$ iç tutarlılık katsayısı $(0,955)$ olarak hesaplanmıştır. 
Tablo 2. Örgütsel Adalet Ölçeği Temel Bileşenler ve Güvenirlik Analizi Sonuçları

\begin{tabular}{|c|c|c|c|}
\hline & \multicolumn{3}{|c|}{ Boyut } \\
\hline & 1 & 2 & 3 \\
\hline adalet19 & 877 & & \\
\hline adalet13 & 830 & & \\
\hline adalet20 & 820 & & \\
\hline adalet12 & 816 & & \\
\hline adalet17 & 802 & & \\
\hline adalet14 & 794 & & \\
\hline adalet18 & 790 & & \\
\hline adalet16 & 789 & & \\
\hline adalet15 & 779 & & \\
\hline adalet11 & & 769 & \\
\hline adalet9 & & ,730 & \\
\hline adalet8 & & 713 & \\
\hline adalet10 & & 687 & \\
\hline adalet7 & & 681 & \\
\hline adalet2 & & & 880 \\
\hline adalet1 & & & 841 \\
\hline adalet3 & & & ,830 \\
\hline adalet4 & & & 612 \\
\hline Eigen Değeri & 10,409 & 1,878 & 1,267 \\
\hline Açıklanan Varyans (\%) & 37,781 & 19,055 & 18,467 \\
\hline Madde Sayısı & 9 & 5 & 4 \\
\hline Cronbach $\alpha$ & .964 & .888 & .872 \\
\hline KMO-MSA & & 0,917 & \\
\hline Bartlett's (p) & & .000 & \\
\hline
\end{tabular}

Rotasyon Yöntemi: Kaiser Normalizasyonlu Varimax

Tablo 2'de görüldüğü gibi ölçeğin ilk bileşeni olan “etkileşim adaleti" boyutu 9 maddeden oluşmakta ve varyansın \%37,781'ini açıklamaktadır. Etkileşim adaleti boyutuna ait cronbach $\alpha$ iç tutarlılık katsayısı (0,964) olarak hesaplanmıştır. Ölçeğin ikinci bileşeni olan "prosedürel adalet" boyutu 5 maddeden oluşmakta ve varyansın $\% 19,055$ 'ini açılamaktadır. Prosedürel adalet boyutuna ait cronbach $\alpha$ iç tutarlılık katsayısı (.888) olarak hesaplanmıştır. Ölçeğin üçüncü bileşeni olan "dağıtım adaleti" boyutu 4 maddeden oluşmakta ve varyansın \%18,467' sini açıklamaktadır. Dağıtım adaleti boyutuna ait cronbach $\alpha$ iç tutarlılık katsayısı $(0,872)$ olarak hesaplanmıştır. 
$\mathrm{Bu}$ analizlerin yanı sıra, ölçeğin kapsam, görünüş geçerliliği ve kullanışlılık geçerliliğinin sağlanması amacıyla ölçek örnekleme dağıtılmadan önce üç alan uzmanı ve üç Türk Dili uzmanına gönderilerek fikirleri alınarak son haline getirilmiştir.

Tüm bu değer ve sonuçlara bakılarak ölçeğin geçerlilik ve güvenilirlik açılarından kullanılabilir olduğu sonucuna ulaşılmıştır.

\section{Etik Ölçĕgi}

Kullanılan diğer ölçme aracı Topaloğlu (2010) tarafından geliştirilen ve kullanılması için gerekli izin alınan etik ölçeğinin içerdiği 10 soru tek bir boyutta toplanmaktadır. Ölçek maddelerinin faktör yükleri $(0,879)$ ile $(0,711)$ arasında değişmektedir. 10 madde tarafından açılanan toplam varyans $\% 65,616$ olarak hesaplanmıştır. Ölçeğe ait cronbach $\alpha$ iç tutarlılık katsayısı (.941)'dir. Ölçeğin örneklem uygunluk değerleri olan KMO-MSA değeri $(0,916)$, Bartlett's $(p)$ değeri ise $(0,000)$ olarak hesaplanmıştır. Ölçek formu hazırlandıktan sonra örnekleme uygulanmadan önce çeşitli branşlardan öğretim üyelerine ve dil uzmanlarına danışılarak kapsam, görünüş ve kullanışlılık geçerliliği sağlanmaya çalışılmıştır.

\section{Örgütsel Adanmışlık Ölçeği}

Akademik personelin adanmışlık düzeylerini ölçmek amacıyla Yıldırım (2009) tarafından geliştirilen ve 12 maddeden oluşan Örgütsel Adanmışlık ölçeği kullanılmıştır. Orijinal ölçek gerekli izinlerin alınmasından sonra kapsam, görünüş ve yapı geçerliliği için uzman görüşüne sunulmuş, onay alınarak anket formuna dâhil edilip örnekleme dağıtılmıştır.

Yapılan temel bileşenler analizi sonuçlarına göre ölçek tek boyutlu bir yapı göstermektedir. Ölçek maddelerinin faktör yükleri $(0,888)$ ile $(0,761)$ arasında değişmektedir. Ölçeğe ait KMO-MSA katsayısı $(0,940)$, Bartlett's (p) değeri $(0,000)^{\prime}$ dır. Açıklanan toplam varyans \%67,244 olarak hesaplanmıştır. Ölçekte bulunan 12 madde için cronbach $\alpha$ iç tutarlılık katsayısı (.955)'dir.

\section{Verilerin Analizi}

Araştırma kapsamında toplanan veriler SPSS paket programına aktarılarak, veri toplama araçları bölümünde belirtilen yapı geçerliliği ve güvenilirlik analizlerinin yanı sıra; araştırmanın amacı ve alt problemler doğrultusunda yüzde, frekans gibi betimsel istatistik analizlerine, bağımsız örneklem grubu $t$ testi, tek yönlü varyans analizi gibi çeşitli varyans analizlerine ve hiyerarşik lineer regresyon analizine tabi tutulmuştur. 


\section{Bulgular}

Tablo 3. Akademisyenlerin Örgütsel Adalet Alg1S1, Etik Algısı ve Örgütsel Adanmışlık Düzeyi Ortalamaları

\begin{tabular}{lccccc}
\hline & $\mathrm{N}$ & Minimum & Maksimum & $\bar{x}$ & Std. Sapma \\
\cline { 2 - 6 } $\begin{array}{l}\text { Etkileşim } \\
\text { Adaleti }\end{array}$ & 181 & 1,00 & 5,00 & 2,6133 & 1,00367 \\
$\begin{array}{l}\text { Prosedürel } \\
\text { Adalet }\end{array}$ & 181 & 1,00 & 5,00 & 3,0575 &, 97149 \\
Dağıtım Adaleti & 181 & 1,00 & 4,50 & 2,4144 &, 89613 \\
Adalet toplam & 181 & 1,00 & 4,78 & 2,6924 &, 85190 \\
Etik toplam & 181 & 1,00 & 5,00 & 2,9536 &, 94296 \\
$\begin{array}{l}\text { Adanmışlık } \\
\text { Toplam }\end{array}$ & 181 & 1,00 & 5,00 & 3,4157 &, 91641 \\
\hline
\end{tabular}

Tablo 3'de akademisyenlerin örgütsel genel adalet algisı ve örgütsel adaletin alt boyutlarındaki ortalamaları, etik algısı ve örgütsel adanmışlık düzeyi ortalamalarına ve diğer betimsel istatistiklere yer verilmiştir. Ortalamaların tümü 1 ila 5 arasında değer alabilmektedir. Akademisyenlerin genel örgütsel adalet alg1 ortalamaları 2,69'dur. $\mathrm{Bu}$ ortalama akademisyenlerin orta düzeyde örgütsel adalet algısına sahip oldukları şeklinde yorumlanabilir. Algılanan örgütsel adaletin alt boyutlarından olan Etkileşim Adaleti'ne ait ortalama 2,61'dir ve orta düzeyde olduğu söylenebilir. Prosedürel Adalet alt boyutunun ortalaması ise 3,06 olarak hesaplanmıştır ve orta düzeyle olduğu söylenebilir. Dağıtım Adaleti boyutunun ortalaması ise 2,41 'dir ve orta düzeyde olduğu söylenebilir. Akademisyenlerin etik algıları ortalaması 2,95 olarak hesaplanmıştır ve yine orta düzeyde olduğu söylenebilir. Son olarak akademisyenlerin örgütsel adanmışlık düzeylerinin ortalaması 3,42 olarak hesaplanmıştır ve akademisyenlerin adanmışlık düzeylerinin yüksek olduğu şeklinde yorumlanabilir.

Tablo 4. Akademisyenlerin Ortalama Örgütsel Adanmışlık Düzeylerinin Cinsiyetlerine Göre Karşılaştırılması (Bağımsız Örneklem Grubu T Testi)

\begin{tabular}{lccccccc}
\hline & Cinsiyet & $\mathrm{N}$ & $\bar{x}$ & Std. Sapma & $\begin{array}{c}\text { Std. } \\
\text { Hata } \\
\text { Ort. }\end{array}$ & $\mathrm{t}$ & $\mathrm{P}$ \\
\cline { 2 - 8 } $\begin{array}{l}\text { Örgütsel } \\
\text { Adanmışlık }\end{array}$ & Erkek & 101 & 3,4101 &, 96175 &, 09570 & - &, 926 \\
Düzeyi & Kadın & 80 & 3,4229 &, 86173 &, 09634 &, 093 &, 926 \\
\hline
\end{tabular}


Tablo 4'de de görüldüğü gibi akademisyenlerin ortalama örgütsel adanmışlık düzeyleri cinsiyetlerine göre istatistiksel olarak anlamlı bir şekilde farklılaşmamaktadır (t: $-0,093$, p: 0.929). Kadın $(\bar{x}: 3,42)$ ve erkek $(\bar{x}$ : $3,41)$ akademisyenlerin adanmışlık düzeyi ortalamaları birbirine çok yakın değerlere sahiptir.

Tablo 5. Akademisyenlerin Ortalama Örgütsel Adanmışlık Düzeylerinin Yaş Gruplarına Göre Karşılaştırılması (Tek Yönlü Varyans Analizi, Tukey Prosedürü)

\begin{tabular}{lcccccc}
\hline & $\begin{array}{c}\text { Kareler } \\
\text { toplami }\end{array}$ & sd & $\begin{array}{c}\text { Kareler } \\
\text { Ortalamas }\end{array}$ & F & p & Fark \\
\cline { 2 - 7 } Gruplar & 4,717 & 5 &, 943 & 1,127 &, 348 & - \\
arası & 146,449 & 175 &, 837 & & & \\
Gruplar içi & 151,167 & 180 & & & & \\
Toplam & 150 & & & & \\
\hline
\end{tabular}

Tablo 5'de de görüldüğü gibi akademisyenlerin ortalama örgütsel adanmışlık düzeylerinin yaş gruplarına göre farklılaşması, istatistiksel olarak anlamlı değildir (F: 1,127, p:0,348). Örgütsel adanmışlık puanlarının yaş gruplarına göre ortalamaları ve diğer betimsel istatistikî değerler tablo 6 'da görülebilir.

Tablo 6. Örgütsel Adanmışlık Puanlarının Yaş Gruplarına Göre Ortalamaları ve Diğer Betimsel İstatistiki Değerler

\begin{tabular}{|c|c|c|c|c|c|c|}
\hline \multirow[t]{2}{*}{$\begin{array}{l}\text { Yaş } \\
\text { Grupları }\end{array}$} & \multirow[t]{2}{*}{$\mathrm{N}$} & \multirow[t]{2}{*}{$\bar{x}$} & \multirow[t]{2}{*}{$\begin{array}{l}\text { Std. } \\
\text { Sapma }\end{array}$} & \multirow[t]{2}{*}{$\begin{array}{l}\text { Std. } \\
\text { Hata }\end{array}$} & \multicolumn{2}{|c|}{$\begin{array}{l}\text { Ortalamalar için sınır } \\
\text { değerler (\%95 güven } \\
\text { aralığ1 için) }\end{array}$} \\
\hline & & & & & Alt sinir & Üst Sinır \\
\hline $0-29$ & 51 & 3,3366 & 1,06288 & 14883 & 3,0377 & 3,6355 \\
\hline $30-34$ & 55 & 3,4136 & 79203 & 10680 & 3,1995 & 3,6278 \\
\hline $35-39$ & 28 & 3,7292 & 76431 & 14444 & 3,4328 & 4,0255 \\
\hline $40-44$ & 30 & 3,2083 & 83813 & 15302 & 2,8954 & 3,5213 \\
\hline $45-50$ & 13 & 3,4487 & 1,20066 & 33300 & 2,7232 & 4,1743 \\
\hline 50 - üzeri & 4 & 3,7083 & 93912 & 46956 & 2,2140 & 5,2027 \\
\hline Toplam & 181 & 3,4157 & ,91641 & ,06812 & 3,2813 & 3,5502 \\
\hline
\end{tabular}


Tablo 6'da Yaş gruplarına göre karşılaştırılan akademisyenlerden, yaşları 40-44 olan akademisyenlerin örgütsel adanmışlık puanları $(\bar{x}: 3,21)$, yaşları 35-39 olan akademisyenlerin örgütsel adanmışlık puanlarından $(\bar{x}$ : 3,73) daha düşük olduğu istatistiksel olarak açıkça görülmektedir.

Tablo 7. Akademisyenlerin Ortalama Örgütsel Adanmışlık Düzeylerinin Medeni Durumlarına Göre Karşılaştırılması (Bağımsız Örneklem Grubu T Testi)

\begin{tabular}{llcccccc}
\hline & & & & \multicolumn{5}{c}{ Std. } \\
Örgütsel & Medeni & & $\bar{N}$ & Std. & Hata & \\
Adanmışlık & Durum & $\mathrm{N}$ & $\bar{x}$ & Sapma & Ort. & $\mathrm{t}$ & $\mathrm{p}$ \\
\cline { 2 - 8 } Düzeyi & Evli & 110 & 3,4076 &, 95298 &, 09086 & - & \multirow{2}{*}{, 88} \\
& Bekâr & 71 & 3,4284 &, 86319 &, 10244 &, 149 & 2 \\
\hline
\end{tabular}

Akademisyenlerin örgütsel adanmışlık düzeylerinin medeni durumlarına göre karşılaştırılması amacıyla yapılan test sonucunda, evli ve bekâr akademisyenlerin örgütsel adanmışlık düzeyleri arasındaki farklılaşmanın istatistiksel olarak anlamlı olmadığı görülmektedir (t: -0,149, p:0,882). Evli $(\bar{x}: 3,41)$ ve bekâr $(\bar{x}: 3,43)$ akademisyenlerin adanmışlık düzeyi ortalamaları birbirine çok yakın değerlere sahiptir.

Tablo 8. Akademisyenlerin Ortalama Örgütsel Adanmışlık Düzeylerinin Akademik Unvanlarına Göre Karşılaştırılması (Tek Yönlü Varyans Analizi, Tukey prosedürü)

\begin{tabular}{lcccccc}
\hline & $\begin{array}{c}\text { Kareler } \\
\text { Toplamı }\end{array}$ & sd & $\begin{array}{c}\text { Kareler } \\
\text { Ortalaması }\end{array}$ & F & p & Fark \\
\cline { 2 - 7 } Gruplar arası & 2,409 & 5 &, 482 &, 567 &, 725 & \\
Gruplar içi & 148,758 & 175 &, 850 & & & - \\
Toplam & 151,167 & 180 & & & & \\
\hline
\end{tabular}

Tablo 8'de de görüldügü gibi akademisyenlerin ortalama örgütsel adanmışlık düzeylerinin akademik unvanlarına göre farklılaşması, istatistiksel olarak anlamlı değildir (F: 0,567, p:0,725). Örgütsel adanmışlık puanlarının akademik unvanlara göre ortalamaları ve diğer betimsel istatistikî değerler tablo 9'da görülebilir. 
Tablo 9. Örgütsel Adanmışlık Puanlarının Akademik Unvanlara Göre Ortalamaları ve Diğer Betimsel İstatistikî Değerler

\begin{tabular}{|c|c|c|c|c|c|c|}
\hline \multirow[t]{2}{*}{$\begin{array}{l}\text { Akademik } \\
\text { Unvan }\end{array}$} & \multirow[t]{2}{*}{$\mathrm{N}$} & \multirow[t]{2}{*}{$\bar{x}$} & \multirow[t]{2}{*}{$\begin{array}{c}\text { Std. } \\
\text { Sapma }\end{array}$} & \multirow[t]{2}{*}{$\begin{array}{l}\text { Std. } \\
\text { Hata }\end{array}$} & \multicolumn{2}{|c|}{$\begin{array}{c}\text { Ortalamalar için } \\
\text { sınır değerler (\%95 } \\
\text { güven aralığı için) }\end{array}$} \\
\hline & & & & & Alt sinir & Üst Sinir \\
\hline $\begin{array}{l}\text { Öğretim } \\
\text { Görevlisi }\end{array}$ & 69 & 3,3466 & 1,05754 & 12731 & 3,0926 & 3,6007 \\
\hline $\begin{array}{l}\text { Okutman- } \\
\text { Uzman }\end{array}$ & 6 & 3,2639 & 70792 & 28901 & 2,5210 & 4,0068 \\
\hline $\begin{array}{l}\text { Araştırma } \\
\text { Görevlisi }\end{array}$ & 41 & 3,4614 & 84965 & 13269 & 3,1932 & 3,7296 \\
\hline Yrd.Doç.Dr & 57 & 3,4167 & 83719 & 11089 & 3,1945 & 3,6388 \\
\hline Doç.Dr & 7 & 3,8452 & ,58813 & 22229 & 3,3013 & 4,3892 \\
\hline Prof.Dr & 1 & 4,1667 & . & & . & . \\
\hline Toplam & 181 & 3,4157 & ,91641 & ,06812 & 3,2813 & 3,5502 \\
\hline
\end{tabular}

Akademik unvanlara bakıldığında Prof. Dr. unvanına sahip akademisyenin örgütsel adanmışlık düzeyi $(\bar{x}: 4,17)$, akademik unvanları okutman-uzman olan akademisyenlerin örgütsel adanmışlık düzeyinden $(\bar{x}$ :3,26) daha yüksektir (Tablo 7).

Tablo 10. Akademisyenlerin Ortalama Örgütsel Adanmışlık Düzeylerinin Kurumda Çalışma Sürelerine Göre Karşılaştırılması (Tek Yönlü Varyans Analizi, Tukey Prosedürü)

\begin{tabular}{|c|c|c|c|c|c|c|}
\hline & $\begin{array}{c}\text { Kareler } \\
\text { Toplamı }\end{array}$ & $\mathrm{sd}$ & $\begin{array}{c}\text { Kareler } \\
\text { Ortalaması }\end{array}$ & $\mathrm{F}$ & p & Fark \\
\hline $\begin{array}{l}\text { Gruplar } \\
\text { arasi }\end{array}$ & 15,968 & 5 & 3,194 & \multirow{3}{*}{4,134} & \multirow{3}{*}{,001 } & \multirow{3}{*}{$\begin{array}{c}\text { Grup1< } \\
\text { Grup2 }\end{array}$} \\
\hline Gruplar içi & 135,198 & 175 & 773 & & & \\
\hline Toplam & 151,167 & 180 & & & & \\
\hline
\end{tabular}

Grup 1: 0-3 yıl arası çalışanlar, Grup 2: 4-6 yıl arası çalışanlar

Tablo $10^{\prime}$ da görüldüğü gibi, akademisyenlerin örgütsel adanmışlık düzeyleri kurumda çalışma sürelerine göre istatistiksel olarak anlamlı bir biçimde farklılaşmaktadır (F: 4,134, p:0,001). 
Tablo 11. Örgütsel Adanmışlık Puanlarının Kurumda Çalışma Sürelerine Göre Ortalamaları ve Diğer Betimsel İstatistiki Değerler

\begin{tabular}{|c|c|c|c|c|c|c|}
\hline \multirow[t]{2}{*}{$\begin{array}{l}\text { Çalışma } \\
\text { Süresi }\end{array}$} & \multirow[t]{2}{*}{$\mathrm{N}$} & \multirow[t]{2}{*}{$\bar{x}$} & \multirow[t]{2}{*}{$\begin{array}{c}\text { Std. } \\
\text { Sapma }\end{array}$} & \multirow[t]{2}{*}{$\begin{array}{l}\text { Std. } \\
\text { Hata }\end{array}$} & \multicolumn{2}{|c|}{$\begin{array}{l}\text { Ortalamalar için sinır } \\
\text { değerler (\%95 güven } \\
\text { aralığı için) }\end{array}$} \\
\hline & & & & & Alt sinir & Üst Sinır \\
\hline $0-3$ & 63 & 3,1190 & 94692, & 11930, & 2,8806 & 3,3575 \\
\hline $4-6$ & 44 & 3,7992 & ,81656 & 12310, & 3,5510 & 4,0475 \\
\hline $7-9$ & 22 & 3,7462 & 81669 & 17412, & 3,3841 & 4,1083 \\
\hline $10-12$ & 17 & 3,2010 & 65289 & 15835, & 2,8653 & 3,5367 \\
\hline $13-15$ & 4 & 3,7500 & 1,36253 & 68126, & 1,5819 & 5,9181 \\
\hline $\begin{array}{l}16 \text { ve } \\
\text { üzeri }\end{array}$ & 31 & 3,3145 & 90439 & 16243 & 2,9828 & 3,6462 \\
\hline Toplam & 181 & 3,4157 & 91641 & 06812, & 3,2813 & 3,5502 \\
\hline
\end{tabular}

Kurumda çalışma süreleri 4-6 yıl arasında olan akademisyenlerin örgütsel adanmışlık düzeyleri $(\bar{x}: 3,80)$, çalışma süreleri $0-3$ yıl arasında olan akademisyenlerin örgütsel adanmışlık düzeyinden $(\bar{x}: 3,12)$ daha yüksektir (bkz. Tablo 11).

Tablo 12. Akademisyenlerin Ortalama Örgütsel Adanmışlık Düzeylerinin İdari Görev Alıp Almamalarına Göre Karşılaştırılması (Bağımsız Örneklem Grubu T Testi)

\begin{tabular}{|c|c|c|c|c|c|c|c|}
\hline \multirow{3}{*}{$\begin{array}{l}\text { Örgütsel } \\
\text { Adanmışlık } \\
\text { Düzeyi }\end{array}$} & $\begin{array}{c}\text { İdari } \\
\text { Görevi } \\
\text { Var } \\
\text { m1? }\end{array}$ & $\mathrm{N}$ & $\bar{x}$ & $\begin{array}{c}\text { Std. } \\
\text { Sapma }\end{array}$ & $\begin{array}{l}\text { Std. } \\
\text { Hata } \\
\text { Ort. }\end{array}$ & $\mathrm{t}$ & $\mathrm{P}$ \\
\hline & Hayır & 102 & 3,4281 & 94310 & 09338, & \multirow{2}{*}{0,206} & \multirow{2}{*}{0,837} \\
\hline & Evet & 79 & 3,3998 & ,88649 & 09974 & & \\
\hline
\end{tabular}

Akademisyenlerin örgütsel adanmışlık düzeylerinin idari görevleri olup olmamasına göre karşılaştırılması amacıyla yapılan test sonucunda, idari görevi olmayan ve olan akademisyenlerin örgütsel adanmışlık düzeyleri arasındaki farklılaşmanın istatistiksel olarak anlamlı olmadığı görülmektedir (t: 0,206, p:0,837). 
Tablo 13. İdari Görevi Olan Akademisyenlerin Ortalama Örgütsel Adanmışlık Düzeylerinin İdari Görev Yapma Sürelerine Göre Karşılaştırılması (Tek Yönlü Varyans Analizi, Tukey Prosedürü)

\begin{tabular}{lcccccc}
\hline & $\begin{array}{c}\text { Kareler } \\
\text { toplamı }\end{array}$ & $\mathrm{sd}$ & $\begin{array}{c}\text { Kareler } \\
\text { Ortalaması }\end{array}$ & $\mathrm{F}$ & $\mathrm{p}$ & Fark \\
\cline { 2 - 7 } Gruplar arası & 5,629 & 3 & 1,876 & 2,528 &, 064 & \\
Gruplar içi & 55,668 & 75 &, 742 & & & - \\
Toplam & 61,297 & 78 & & & & \\
\hline
\end{tabular}

Tablo 13'de de görüldüğü gibi idari görevi olan akademisyenlerin ortalama örgütsel adanmışlık düzeylerinin idari görev yapma sürelerine göre farklılaşması, istatistiksel olarak anlamlı değildir (F: 2,528, p:0,064). Örgütsel adanmışlık puanlarının idari görev yürütme sürelerine göre ortalamaları ve diğer betimsel istatistiki değerler tablo 14 'de görülebilir.

Tablo 14. Örgütsel Adanmışlık Puanlarının İdari Görev Yürütme Sürelerine Göre Ortalamaları ve Diğer Betimsel İstatistiki Değerler

\begin{tabular}{|c|c|c|c|c|c|c|}
\hline \multirow[t]{2}{*}{$\begin{array}{l}\text { Görev } \\
\text { Süresi }\end{array}$} & \multirow[t]{2}{*}{$\mathrm{N}$} & \multirow[t]{2}{*}{$\bar{x}$} & \multirow[t]{2}{*}{$\begin{array}{c}\text { Std. } \\
\text { Sapma }\end{array}$} & \multirow[t]{2}{*}{$\begin{array}{l}\text { Std. } \\
\text { Hata }\end{array}$} & \multicolumn{2}{|c|}{$\begin{array}{c}\text { Ortalamalar için sınır } \\
\text { değerler (\%95 güven aralığ } \\
\text { için) }\end{array}$} \\
\hline & & & & & Alt sinir & Üst Sınır \\
\hline $0-1$ & 26 & 3,0481 & 98831 & 19382, & 2,6489 & 3,4473 \\
\hline $2-4$ & 40 & 3,6333 & 77183 & 12204 & 3,3865 & 3,8802 \\
\hline $5-7$ & 4 & 3,5833 & 1,17260 & ,58630 & 1,7175 & 5,4492 \\
\hline $\begin{array}{l}8 \text { ve } \\
\text { üzeri }\end{array}$ & 9 & 3,2963 & 69736 & 23245 & 2,7603 & 3,8323 \\
\hline Toplam & 79 & 3,3998 & 88649 & 09974 & 3,2012 & 3,5984 \\
\hline
\end{tabular}

Tablo 14'de İdari görev yürütme süreleri açısından akademisyenlerin örgütsel adanmışlık düzeyleri ve diğer istatistiki değerler yer almaktadır. Buna göre 2-4 yıl idari görev yürüten akademisyenlerin örgütsel adanmışlık düzeyleri ( $\bar{x}: 3,63), 0-1$ yıl idari görev yürüten akademisyenlerin örgütsel adanmışlık düzeylerinden $(\bar{x}: 3,05)$ daha yüksektir. 
Tablo 15. Örgütsel Adalet, Etik Algısı ve Bazı Demografik Değişkenlerin Örgütsel Adanmışlığı Yordama Düzeylerini Gösteren Hiyerarşik Lineer Regresyon Modeli

\begin{tabular}{|c|c|c|c|c|c|c|c|c|c|}
\hline \multirow[b]{2}{*}{$\begin{array}{l}\text { Mod } \\
\text { el }\end{array}$} & \multirow[b]{2}{*}{$\mathrm{R}$} & \multirow[b]{2}{*}{$\mathrm{R}^{2}$} & \multirow{2}{*}{$\begin{array}{c}\mathrm{Dü} \\
\text { zeltil } \\
\text { miş } \\
\mathrm{R}^{2} \\
\end{array}$} & \multirow[b]{2}{*}{$\begin{array}{c}\text { [ahminin } \\
\text { Std. } \\
\text { Hatası } \\
\end{array}$} & \multicolumn{5}{|c|}{ Değişim İstatistikleri } \\
\hline & & & & & $\begin{array}{l}\mathrm{R}^{2} \text { deki } \\
\text { )eğişim }\end{array}$ & $\begin{array}{c}F^{\prime} \text { deki } \\
\text { Değişim }\end{array}$ & Sd1 & $\mathrm{Sd} 2$ & $\begin{array}{c}\mathrm{F}^{\prime} \\
\text { değişiminin } \\
\text { Anlamllı̆̆ğ1 } \\
\end{array}$ \\
\hline 1 & ,579(a) & ,336 & ,309 & 73691 & ,336 & 12,626 & 3 & 75 & , 000 \\
\hline 2 & ,633(b) & ,401 & ,369 & ,70424 & ,066 & 8,120 & 1 & 74 & ,006 \\
\hline 3 & ,682(c) & 465 & 387 & 69418 & ,064 & 1,360 & 6 & 68 & 243 \\
\hline
\end{tabular}

Model 1Yordayıcılar: (Sabit), Etkileşim Adaleti, Dağıtım adaleti, Prosedürel Adalet

Model 2Yordayıcılar: (Sabit), Etkileşim Adaleti, Dağıtım adaleti, Prosedürel Adalet, etik toplam Model 3Yordayıcılar: (Sabit), Etkileşim Adaleti, Dağıtım adaleti, Prosedürel Adalet, etik toplam, akademik unvan, medeni durum, kurumda çalışma süresi, cinsiyet, idari görev süresi, yaş

Tablo 15 'de örgütsel adalet, etik algısı ve akademik unvan, medeni durum, kurumda çalışma süresi, cinsiyet, idari görev süresi, yaş gibi bazı demografik değişkenlerin akademisyenlerin örgütsel adanmışlıklarını yordama düzeyleri gösterilmiştir. Bağımsız değişkenler birinci blokta örgütsel adalet ölçeğinin boyutları, ikinci blokta etik algısı ve üçüncü blokta ise demografik değişkenler olmak üzere üç blok olarak hiyerarşik lineer regresyon modeline dâhil edilmiştir.

Elde edilen bulgulara göre ilk blokta yer alan Etkileşim adaleti, Prosedürel adalet, Dağıtım adaleti değişkenleri birlikte akademisyenlerin örgütsel adanmışlık düzeylerinin \%33,6'sını açıklamaktadır (R: 0,579, p:0,000). İkinci blokta yer alan etik algısı bağımsız değişkeni ise bağımlı değişken olan örgütsel adanmışlık düzeyinin \%6,6'sını açılamaktadır (R: 0,633, p:0,006). Modelin son bloğunda yer alan akademik unvan, medeni durum, kurumda çalışma süresi, cinsiyet, idari görev süresi ve yaş değişkenleri ise birlikte örgütsel adanmışlık düzeyinin $\% 6,4^{\prime}$ ünü açıklamaktadır (R: 0,682, p:0,243).

Hiyerarşik regresyon modeli sonuçlarına göre üç blok halinde yer alan bağımsız değişkenler akademisyenlerin örgütsel adanmışlık düzeylerinin toplamda \%46,5'ini açıklamaktadır. 
Tablo 16. Hiyerarşik Lineer Regresyon Modeline İlişkin Katsayılara

\begin{tabular}{|c|c|c|c|c|c|c|}
\hline \multirow[t]{2}{*}{ Model } & & \multicolumn{2}{|c|}{$\begin{array}{c}\text { Standartlaştırılma } \\
\text { mış Regresyon } \\
\text { Katsayıları } \\
\end{array}$} & \multicolumn{3}{|c|}{$\begin{array}{c}\text { Standartlaştırılmış } \\
\text { Regresyon } \\
\text { Katsayıları } \\
\end{array}$} \\
\hline & & B & Std. Hata & B & $\mathrm{t}$ & $p$ \\
\hline \multirow{5}{*}{1} & (sabit) & 1,538 & ,319 & & 4,815 & 000 \\
\hline & Prosedürel adalet & 288 & 144 & ,288 & 2,002 & 049 \\
\hline & Dağıtım adaleti & ,367 & 107 & ,363 & 3,420 & 001 \\
\hline & Etkileşim adaleti & ,040 & ,136 & ,042 & ,291 & 772 \\
\hline & (sabit) & 1,258 & ,321 & & 3,922 & , 000 \\
\hline \multirow{3}{*}{2} & Prosedürel adalet & ,061 & ,159 & ,060 & ,380 & ,705 \\
\hline & Dağıtım adaleti & 339 & 103 & ,335 & 3,289 & ,002 \\
\hline & Etkileşim adaleti &,- 176 & 151 &,- 187 & $-1,167$ & 247 \\
\hline \multirow{12}{*}{3} & Etik toplam &, 538 & 189 & ,509 & 2,850 & ,006 \\
\hline & (sabit) & 1,412 &, 542 & & 2,606 & ,011 \\
\hline & Prosedürel adalet &,- 020 & 167 &,- 020 &,- 122 & ,903 \\
\hline & Dağıtım adaleti & ,403 & 117 & 398 & 3,455 & 001 \\
\hline & Etkileşim adaleti &,- 212 & 167 &,- 226 & $-1,269$ & 209 \\
\hline & Etik toplam &, 573 & 198 &, 543 & 2,890 & 005 \\
\hline & Cinsiyet &,- 026 & 185 &,- 014 &,- 140 & 889 \\
\hline & Yaş & ,012 & 108 & 019 & 115 & ,909 \\
\hline & Medeni durum &,- 212 & 210 &,- 097 & $-1,008$ & ,317 \\
\hline & Akademik unvan & ,038 & ,055 & ,068 & 691 & ,492 \\
\hline & $\begin{array}{l}\text { Kurumda çalışma } \\
\text { süresi }\end{array}$ &,- 106 & ,065 &,- 240 & $-1,628$ & 108 \\
\hline & İdari Görev Süresi & ,228 & 110 & ,236 & 2,071 & 042 \\
\hline
\end{tabular}

a Bağımlı Değişken: Örgütsel Adanmışlık Düzeyi

Regresyon modeline dâhil edilen standartlaştırılmış ve standartlaştırılmamış regresyon katsayıları Tablo $16^{\prime}$ da verilmiştir. Model bloklar halinde ele alındığında bir blokta yer alan değişkenlerin tamamı regresyon formülüne sokularak toplam etki ve yordama düzeyi hesaplanmaktadır. Bloklara dâhil edilen her değişkenin tek tek etki düzeyinin ve etkinin istatistiksel olarak anlamlı olup olmadığının detaylı incelenebilmesi için regresyon katsayılarına bakılmalıdır. Her üç bloğu da kapsayan son (üçüncü model) regresyon modelinde örgütsel adanmışlık düzeyinin açılanan toplam varyansına istatistiksel olarak anlamlı etkide bulunan bağımsız değişkenler; örgütsel adalet boyutlarından Dağıtım adaleti, örgütsel etik algısı ve idari görev süresidir. 


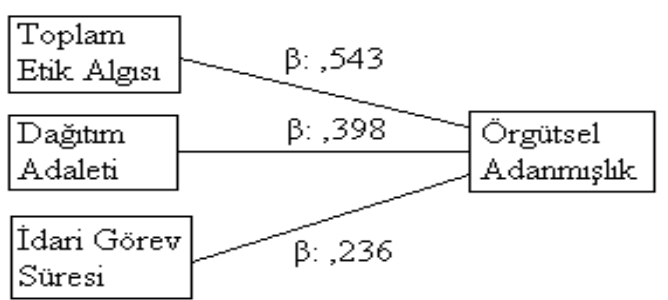

Şekil 1. Hiyerarşik Lineer Regresyon Analizi Sonuçlarının Modellenmesi

Bu sonuçlara göre bağımlı değişken olan örgütsel adanmışlık düzeyi üzerinde en fazla etkiye sahip olan bağımsız değişken örgütsel etik algısıdır ( $\beta: 0,543, p: 0,005)$. Örgütsel adalet algisı boyutlarından Dağıtım adaleti bağımsız değişkeni örgütsel adanmışlık düzeyi üzerinde en fazla etkiye sahip ikinci faktördür ( $\beta$ : $0,398, p: 0,001)$. Örgütsel adanmışlık düzeyi üzerinde nispeten daha az etkiye sahip olan diğer bağımsız değişken ise idari görev süresidir ( $\beta: 0,236$, p:0,042). (Şekil 1)

\section{Sonuç ve Öneriler}

$\mathrm{Bu}$ çalışma akademisyenlerin çalışma ortamlarında algıladıkları adaletin ve etiğin örgütsel adanmışlık düzeylerine etkisinin olup olmadığını incelemek amacıyla yapılmıştır.

Tablo 17. Akademisyenlere ilişkin algısal ortalamalar

Boyut

Genel Örgütsel Adalet

Etkileşim Adaleti

Prosedürel Adalet

Dağıtım Adaleti

Etik Alg1s1

Örgütsel Adanmışlık Genel
Ortalamalar $(5.00, \mathrm{~N}=181)$

2,69

2,61

3,06

2,41

2,95

3,42

Tablo 17'de açıkça görüldüğü üzere akademisyenlerin adalet ve etik algılamalarının orta seviyelerde, örgütsel adanmışlık düzeylerinin ise yüksek olduğunu söyleyebiliriz.

$\mathrm{Bu}$ araştırmaya katılan akademisyenlerin çalıştıkları kurumdan ve yaptıkları işten gurur duydukları, sosyal statü ve itibar ile motive oldukları ve bu nedenle kurum içerisinde adaletsizlik olduğuna ilişkin bir algiya sahip olsalar bile bu durumun örgütsel adanmışlık düzeylerine fazla etkisinin olmadığı ve kendilerini yaptıkları iş ile özdeşleştirdikleri şeklinde 
yorumlanabilir. Ralston vd. (1999: 658), kendini geliştirme düzeyi yüksek olan bireylerin güç ve bireysel başarı ile motive olduklarını ifade etmiştir. Dolayısıyla akademik personele ilişkin yapılmış çalışmalar sınırlı olduğu için bu bulgu genellenebilir bir nitelik taşımamaktadır.

Özellikle faaliyet alanı gereği, insanla ilgilenilen bir sektör olan eğitim sektörünün en üst noktası olarak kabul edilen üniversitede, bizzat bu işi yapan akademisyenlerin, gelecek nesillerin şekillendirilmesinde önemli işlevleri yerine getirmektedirler. Bu durum göz önüne alındığında; bu kurumlarda çalışanların örgütlerine karşı geliştirecekleri adanmışlık duygularının düzeyi, şüphesiz ki gerek örgütsel gelişmeyi gerekse yaptıkları işe daha istekli sarılmalarında önemli etkenlerden olacaktır. Bu doğrultuda, çalışanların örgütlerine olan adanmışlık düzeylerini artırıcı yönde uygulamalara işlerlik kazandırılması, gelişime yönelik önemli yönde katkı sağlayacaktır. Örneğin ders dağılımının yapılmasında ya da oda, laboratuar ve teçhizat kullanımının sağlanmasında eşit ve adil davranılması gibi çalışanların adalet algısına önemli ölçüde katkı sağlayan etkenlere daha çok dikkat edilebilir. Örgütsel adanmışlığın oluşturulmasında ve sürekli hale getirilmesinde çalışanların olduğu kadar üst yönetiminde çok etkin rolü olduğu bilinmeli ve bu durum kesinlikle göz ardı edilmemelidir.

\section{Kaynakça}

Adams, J. S. (1965). "Inequity in Social Exchange", L. Berkowitz (Ed.) Advances in Experimental Social Psychology, Vol.2, New York Academic Press, ss. 267-299, aktaran FOLGER, Robert and Russell Cropanzano; (1998), Organizational Justice and Human Resource Management, Sage Publications, Thousand Oaks London, New Delhi.

Allen, N.J., Meyer, J.P. (1990). "The Measurement and Antecedents of Affective, Continuance and Normative Commitment to the Organization", Journal of Occupational Psychology, 63(1).

Balay, R. (2000). Yönetici ve Öğretmenlerde Örgütsel Bağlılık. Ankara:Nobel Yayıncilık

Balcı, A. (2000). Sosyal Bilimlerde Araştırma, Yöntem Teknik ve İlkeler.Ankara: Pegem A.

Celep, C. (2000). Eğitimde Örgütsel Adanma ve Öğretmenler. Ankara: Anı Y.

Cihangiroğlu N. (2010). Selçuk Üniversitesi Sosyal Bilimler Dergisi sayı 13

Colquitt, Jason A., Donald E. Conlon, Michael J. Wesson, Christopher O. L. H. Porterand K. Yee Ng. (2001). "Justice at the Millennium: A MetaAnalytic Review of 25 Years of Organizational Justice Research", Journal of Applied Psyhology, Vol.86, No.3, ss. 425-445. 
İnce, M.,ve Gül, H. (2005). Yönetimde Yeni Bir Paradigma: Örgütsel Bağlllık. Konya: Çizgi Yayıncılık

Karasar, N. (2009). Bilimsel Araştırma Yöntemi. Ankara: Nobel Yayınları

Kaya, Pir A. (2008). "Sosyal Adaletin Teorik Çerçevesi Üzerine Bir Değerlendirme",http://www.isguc.org/armaganlar/nusretekin/1/17.pd f,Erişim:07.01.2008, ss.229-243.

Morrow, P.C. (1983). Concept Redundancy In Organizational Research: The Case Of Work Commitment. Academy Of Management. Sayı: 8, S. 486-500.

Özkalp, E. (2001). Sosyolojiye Giriş. Eskişehir: Anadolu Üniversitesi Bilimsel Araştırma Çalışmaları Vakfı Yayınları

Özkalp, E. ve Kırel, C. (2004). Örgütsel Davranış. Eskişehir: Anadolu Üniversitesi Vakfı Yayınları.

Pilla1, Rajnandini, Chester A. Schriesheim and Eric S. W. (1999). "Fairness Perceptions and Trust as Mediators for Transformational and Transactional Leadership: A Two-Sample Study", Journal of Management, Vol. 25, No.6, ss.897- 933.

Ralston, D.A., Thang, N. ve Van- Napier, N.K. (1999). A Comparative Study of the Work Values of North and South Vietnamese Managers. Journal of International Business Studies, Vol. 30, No. 4,655-672.

Schwenk, C.R. (1986). "Information, Cognitive Biases and Commitment to A Course of Action", Academy of Management Review, Vol.11, No.2, pp. 298-310.

Şimşek, M. S., Akgemci, T. ve Çelik, A. (2008). Davranış Bilimlerine Giriş ve Örgütlerde Davranış. Ankara: Gazi Kitapevi.

Topaloğlu, I. G. (2010). İşgörenlerin Adalet Ve Etik Algıları Açısından Örgütsel Güven İle Örgütsel Bağlllık İlişkisi. Yüksek Lisans Tezi Atılım Üniversitesi Sosyal Bilimler Enstitüsü.

Tuncer, A. (1995). MEB Bilgisayar Eğitimi Ve Hizmetleri Genel Müdürlüğü Personelinin İş Doyumu Ve Örgüte Bağlılık Durumları. (Yayınlanmamış Yüksek Lisans Tezi) Türkiye Orta Doğu Amme İdaresi Enstitüsü.

Türk Dil Kurumu Sözlüğü, <http://www.tdk.gov.tr/TR/SozBul.aspx> adresinden 01 Mart 2013 tarihinde alınmıştır.

Varoğlu, D. (1993). Kamu Sektörü Çalışanlarının İşlerine ve Kuruluşlarına Karşı Tutumları, Bağlılıkları ve Değerleri. Doktora Tezi, Ankara Üniversitesi Sosyal Bilimler Enstitüsü.

Yıldırım, T. (2009). "İlköğretim Okullarında Görevli Yöneticilerin Kişisel ve Örgütsel Değer Uyumunun Örgütsel Adanma ve Yabancılaşma Üzerine Etkisi", Yüksek Lisans Tezi, Uşak Üniversitesi Sosyal Bilimler Enstitüsü, Uşak. 